\title{
The Ursula Faince Dinnerware Series by Royal Copenhagen
}

\author{
Moeran, Brian
}

Document Version

Final published version

Publication date:

2011

\section{License \\ CC BY-NC-ND}

Citation for published version (APA):

Moeran, B. (2011). The Ursula Faince Dinnerware Series by Royal Copenhagen. Copenhagen Business School [wp].

Link to publication in CBS Research Portal

\section{General rights}

Copyright and moral rights for the publications made accessible in the public portal are retained by the authors and/or other copyright owners and it is a condition of accessing publications that users recognise and abide by the legal requirements associated with these rights.

\section{Take down policy}

If you believe that this document breaches copyright please contact us (research.lib@cbs.dk) providing details, and we will remove access to the work immediately and investigate your claim. 
Creativity at Work:

\section{The Ursula Faience Dinnerware Series by Royal Copenhagen}

By Brian Moeran

August 2011 


\section{(C) R E A}

\section{Abstract}

This working paper is a case study about the development of a faience product line in Royal Copenhagen and illustrates several aspects of how, at what stages of development, and by whom, cultural products in general are evaluated. Three theoretical issues emerge. One concerns the constraints imposed upon design and production by the use of materials and, to a lesser extent, technology. Another argues that product development has to take place within a particular brand and genre - in this case, those of Royal Copenhagen. A third reveals the way in which the design and manufacture of a particular cultural product had to be negotiated within a particular organizational world embracing both management and workers, with differentiated skills. These issues lead to a more general discussion of craftsmanship and storytelling.

\section{Keywords}

Ceramics, Corporate culture, Craft, Marketing, Materials, Product development, Story-telling 


\title{
The Ursula Faience Dinnerware Series by Royal Copenhagen
}

\author{
Brian Moeran
}

In 1993, Royal Copenhagen broke with its porcelain tradition and launched a new faience dinnerware series, which it called Ursula after the potter who designed it, Ursula Munch-Petersen (b. 1937). ${ }^{1}$ The fourth generation of potters living and working on the island of Bornholm in the Baltic Sea, east of Denmark and south of Skåne in Sweden, Ursula Munch-Petersen worked as 'artist in residence' at the Royal Copenhagen factory in Frederiksberg (a borough of Copenhagen city) from the late 1980s into the early 90s. It was then that she designed the Ursula series and, together with a number of colleagues at the factory, nursed it into production.

This case describes various evaluative practices, or 'editorial moments', that took place during the conception, design, manufacturing processes, production, distribution, and sale of the Ursula series. In the process, it reveals actors' perceptions of Ursula Munch-Petersen as a potter and craftswoman, as well as of Royal Copenhagen as a company.

\section{A Tale of Two Factories}

Ursula Munch-Petersen's training in ceramics was broad and closely linked to mass production practices. After childhood exposure to her mother's pottery, Ursula worked for a couple of years in a well-known Danish pottery turning out 'functional art' wares (brugskunst) before starting at the School of Arts and

\footnotetext{
1 The material presented here is based on two visits to the Royal Copenhagen factory in Glostrup, Copenhagen, as well as on interviews with the potter herself; with Finn Næss Schmidt, product development manager at Royal Copenhagen during the time that Ursula was developed and put into production; with Peter Poulsen, chemical engineer who worked on the glazes used in the series; and with Ole Jensen, a designer who was also an 'artist in residence' at Royal Copenhagen with Ursula Munch-Petersen. I would like to thank all those concerned for their time, enthusiasm, patience, and mutual respect.

It was a custom to use working people's names for designs made at Aluminia, one of Royal Copenhagen's factories. A green glazed ware was called Sigurt, for example, and another, blue glazed, one Sonja.

Page 3 of 23 Creative Encou7nters Working Paper \# 62
} 


\section{(C) $\mathrm{R}$ E}

Crafts in Copenhagen, in 1956. After graduation in 1960, she spent a year working in her grandfather's terracotta factory on Bornholm, before finding employment in an experimental workshop located in the Bing \& Grøndahl ceramics factory (where her aunt Gertrude had worked from 1949-59). This gave her an opportunity to show her work in a number of exhibitions both in Denmark and abroad. From 1970-75, Ursula worked at home on a series of saltglazed wares for home use. During this period, she was employed at the School for Arts and Crafts (Skolen for brugskunst), where she held a position until 1990. In 1982, she published a book titled Clay Forming (Lerforming).

Her work has been strongly influenced by folk craft utensils, as well as by her long-standing interest in botany, whose methods of taxonomy influenced the form typologies that she eventually developed for the Ursula faience dinnerware. The latter was put into production by Royal Copenhagen in 1993, with considerable initial success, winning the Design Plus Prize that year in Germany. Ursula Munch-Petersen has, since then, tried to combine precise, functional internal forms with 'accidental' and natural external forms and decoration.

In 1985, after spending the best part of a decade working in Bing \& Grøndahl, a pottery factory located in Copenhagen, Ursula Munch-Petersen was invited to make a dinnerware series by Erik Magnussen, a fellow student during her years at the School of Arts and Crafts, who was then artistic consultant to the company.

"This was when the Ursula idea all started, although the year before I'd
made a 'serving set' (serveringsdele) for a show at the Industrial Arts
Museum (Kunstindustrimuseet) in Copenhagen. The well-known cookbook
writer, Camilla Plum, used it in the museum café to serve food on one
weekend. I decided to develop this idea and design a simple set of serving
dishes: a large oval dish, three or four smaller dishes, and a raised cake
plate of the kind Camilla Plum had used."

While she was perfecting her designs for the Ursula series, however, Bing \& Grøndahl was taken over by the Royal Porcelain Factory (Den Kongelige Porcelainsfabrik), as it was then called, and in 1987 the new company of Royal Copenhagen was formed. After a period of uncertainty, Ursula suggested that Royal Copenhagen produce a simple series of pots that she had in mind for serving food - a large oval dish, four other smaller dishes, and a cake plate. The new management, however, was unable to come to a decision: at times it said yes; at other times, no. In 1988, just as she was beginning to despair, Ursula was awarded a three-year bursary by the Danish Arts Council (Statsfonden). This obliged Royal Copenhagen to provide her with a workshop, and with what she called a 'symbolic salary' as she gave up teaching and devoted herself full-time to designing the Ursula series.

Things did not go at all smoothly, however, in large part because of the new company's management style. Finn Næss, product development manager at the time, explained things in detail:

Page 4 of 23 Creative Encou7nters Working Paper \# 62 
“One of my jobs was to oversee all the young artists who were taken on by the Royal Porcelain Factory at that time. So when Ursula Munch-Petersen arrived, she naturally came under my care. I had to deal with all sorts of socalled 'artists' and a lot of them were extremely egocentric and selfconfident. But not Ursula. Ursula immediately came across as different. She was really humble, right from the start. She was someone who wanted to learn. I liked that. We all did.

"When she came to the factory, Ursula brought with her a limited range of utensils that she'd made in her studio at home. But they were still pretty primitive so far as their development as products was concerned. The forms weren't properly finished, and the glazes weren't at all even, or anything like that. All in all, you could say that they were very much based on a concept of something that was hand made. So we had a lot of work to do to develop that concept into something that could be sold as a Royal Copenhagen product."

A major problem, however, was how best to reconcile different corporate cultures. Finn Næss continued:

“Compared with the Royal Porcelain Factory, Bing \& Grøndahl always treated its artists extremely well and the company developed a milieu that enabled both close contact with management and fine artistic work. The trouble was that a lot of this artistic work didn't sell very well. And because there was a lot of it coming off the production line, Bing \& Grøndahl found itself with a large stone hanging round its neck, dragging it down. That's why it was taken over by the Royal Porcelain Factory and the two of them merged into Royal Copenhagen.

“Unlike Bing \& Grøndahl, the Royal Porcelain Factory didn't place all its artists together in one big workshop. Rather they distributed them around according to their particular speciality. So a sculptor would be placed in the modelling room, and a painter in the painting room. And so on and so forth. This meant that, after Bing \& Grøndahl was taken over, it was difficult to separate their artists physically because they were used to being all together.

"There was also a totally different chemistry between artists and management. At the Royal Porcelain Factory, senior management didn't come and see what their artists were up to every day or two or three times a week, in the way they used to do at Bing \& Grøndahl. Instead, they told their artists to display all their work in one room once every three months and the new Royal Copenhagen leadership would turn up in their fine suits and ties, look around at what was on display, and say things like, 'that's OK, ' that's no good', and so on and so forth. This was the way they selected work for further development or rejected it for the dustbin.

“During this process, the artists weren't allowed to be present. So it was my job to find out what was right or wrong about each of the products and let the artists concerned know. But they never got a chance to hear anything directly from senior managers. Nor were they able to question their 
decisions or explain to the leadership why they were doing things the ways they were.

“Of course, two or three of Bing \& Grøndahl's former managers were there, too, because they'd also become part of Royal Copenhagen after the merger. So there were two totally different worlds at work in the same room. On the one hand, there were the old Royal Porcelain Factory lot, in their fine suits and colourful ties. And, on the other, there were these really down-to-earth production-oriented people from Bing \& Grøndahl. And, of course, they had totally different opinions about what was 'good' and what was 'bad', about what was worth developing further and what wasn't.

"And Ursula's work was something they really disagreed on. The Royal Porcelain Factory managers thought her work was 'a little primitive' and asked what the point was in having her kind of work included in the Royal Copenhagen production line. The Bing \& Grøndahl people, with whom Ursula had developed very strong connections during her time there, thought it really exciting and imaginative.

"As you can imagine, this was a dilemma for both sides. What were they going to say to Ursula who, let's face it, had a big vision? The Royal Porcelain Factory managers just didn't like this kind of work, while the Bing \& Grøndahl managers obviously did. In the end, the Royal Porcelain Factory lot pretended to like what Ursula Munch-Petersen was doing. Privately, though, they said her work would never sell. It was all a matter of internal management politics. The two groups had to keep face."

\section{Clay and Glazes}

Corporate structure, management and production practices all had an effect upon the final outcome of the Ursula dinnerware range. But there were also a number of technical aspects that came into play, particularly with regard to form and decoration (glazing).

There was sound reasoning behind Ursula Munch-Petersen's decision to work with faience clay, rather than with porcelain. As she put it:

"I personally like faience, what people call the 'poor man's porcelain' (fattigmands porcelain), but most artists or craftsmen at that time preferred the real thing: porcelain. In fact, even though the production of faience is said to be 'cheap', it's just as expensive as, perhaps a bit more so than, porcelain. This was when people were producing stuff that was the last of the Bauhaus effect. Everything had to be B\&O kind of design - very clean, very minimalist. The designer Greta Meier's dinnerware is probably typical of the period. Minimalist colours like grey and brown were used for everything in the 40 s and 50 s...

"Anyway, so far as I was concerned, faience was what was interesting because you could get such fantastic colours with it. Royal Copenhagen had bought up a faience factory called Aluminia quite a long time previously. As a result they had a treasure archive of glazes that nobody ever used. It was these that I wanted to try out on my Ursula line..." 


\section{(C)R E A T I V E E N C O U N T E R S}

Faience ware is fired twice. First, pots are fired to a comparatively high temperature of $1160^{\circ}$ or so. Then they are spray glazed and re-fired to a lower temperature of about $1065^{\circ}$. The two firings prevent the pots from being porous. Both the clay and the transparent glaze materials - feldspar and quartz - are natural and purchased from Cornwall in England. Synthetic pigments are weighed, mixed and added for the different coloured glazes. Peter Poulsen added:

"We don't have any problems with new batches of materials nowadays, although we did in the past. Everything's advanced a lot technically speaking, so materials are almost 100 per cent consistent from one batch to the next, and we don't need to make adaptations to our recipes. Still, we tend to draw on old and new batches of mixed ingredients at the same time, just to make sure."

Although not trained in chemistry, like Peter Poulsen, Ursula Munch-Petersen, like all potters, used to make glaze tests in her kiln at home and wrote down all her recipes and results meticulously to ensure repeat results. However, working with faience at Royal Copenhagen proved to be a challenge, firstly, because faience is very different from earthenware or stoneware, which Ursula was used to, and secondly, because of the different kilns and firing methods used.

"I soon learned that firing glazes at home and firing them at the factory were rather different things. In my own kiln, I could make adaptations as I went along, by increasing the temperature, adding more air to the fire, and so on. But Royal Copenhagen used a tunnel kiln. Pots went in one end and came out the other. There was nothing you could do in-between..."

The man she worked with closely on developing glazes for the Ursula series was Peter Poulsen:

“Ursula's samples had been glazed at home and were for earthenware basically. Not for faience. This meant that they had to be adapted, and that we had to find glazes that would fit the faience clay body used by Royal Copenhagen. That was my job, and Ursula and I worked quite closely together, making adaptations to test results as we went along. We'd agree that one glaze was a bit too transparent, for example, and needed more yellow in it. Things like that."

Although they clearly got on very well together, they soon found themselves in difficulty.

“There were two problems," explained the potter. "Firstly, we couldn't use a lot of the old glazes because of new working environment improvements that came in during the 1950s and 60s. A number of restrictions were introduced on materials like cadmium and chrome, for example, that poisoned the atmosphere in the workshops. This meant that a lot of old glaze tests that were really nice just couldn't be used any more.

"So we had to develop new glazes or adaptations of old ones. At first, I wanted ten different glazes: yellow, blue, reddish brown, light green, green, dark green, grey, lavender blue, black, translucent white, and transparent. I 


\section{(C) R E A T I V E E N C O U N T E R S}

planned to use as many as I could, within reason, on each form, so that a medium-sized dish, for example, would be made in all ten colours.

"This led to a second problem. In pottery factories in Germany, for example, a minimum number of forms are manufactured in a large number of different colours. Royal Copenhagen, on the other hand, was exactly the opposite. It produced a large number of forms in just one or two colours. I wanted them to change to the German style, because it made financial sense, and the pots would look better. I mean, you can change production colours from one day to the next, but not forms. They take ages to get right. But Royal Copenhagen refused. They're still working in the same way today. Multiple forms and few colours."

Exactly why the company refused to cooperate or what the problems were remains unclear. Peter Poulsen later commented:

"I think Ursula was too ambitious in one respect. She wanted to have every single one of the pots in the Ursula dinnerware range in all of the colours that we developed. Her ideas were all right in principle, but they were too difficult to carry out in actual production."

After starting out with ten different glazes, therefore, potter and chemist found themselves having to drop grey, black, and transparent.

"But then," Ursula continued, "The dark green became a problem because of the tiny amount of lead in the recipe, and we had to drop it. I wanted black instead, but the Royal Copenhagen marketing people wanted nothing of it and eventually we settled on the grey. They also wanted much more yellow than I did. I myself would have preferred to have had much more white that there currently is...

During our talks, potter and chemist disagreed about the effect of lead in a glaze. According to Ursula:

"Lead doesn't actually do any harm for the most part, even though people make a lot of fuss about it. You see, the fact that a glaze is vitrified prevents harmful substances from coming to the surface of a pot - except if you put some sour liquid in it and leave it there for a considerable length of time."

Peter Poulsen was less sanguine:

"The dark green glaze that we started with had to go, unfortunately, because it contained copper, and copper can seep through a clay body and make it porous. And that won't do with dinnerware that you have to eat off and wash up all the time. I don't care what Ursula herself says. This is the fact. You can't have lead in a dinnerware glaze. So that was the end of the dark green glaze, even though it was really beautiful. Still, we did keep it on the handles of the Ursula cups, because nobody's going to lick them or anything like that. But we couldn't put it on the dishes, or bowls, or jugs, or any of her other dinnerware pots."

Lead wasn't the only problem the two of them faced during their many glaze tests. One dark green glaze that they succeeded in developing (without lead as an ingredient) was rejected because it affected another part of the production 


\section{(C)R E A T I V E E N C O U N T E R S}

process. As we stood in her kitchen admiring a large dark green jug, Ursula explained:

“That glaze isn't so bad either. It's a thinner version of the other... The trouble is Royal Copenhagen said it made their sorting too difficult. You see, the glaze varies in thickness and colour as it melts down the jug's outer form, and in places it's a bit speckled. Royal Copenhagen has always been very particular about sorting firsts from seconds. Look!"

She picked up a very large blue-rimmed white oval dish and showed it to me.

"This is a second because it's got flaws on it here," she pointed to a red crayon mark on the surface of the pot near the rim, and then to another in the centre, "And here. Not those red marks. They wash off. They're there just to indicate where the flaw is. On the rim, it's this tiny spot here. See? In the middle, I don't actually know where it is. And frankly, as a potter, I don't think it matters at all. Anyway, a slight imperfection can add to a pot.

"Still, you can see that, if they're going to be so picky about tiny little spots like these, the sorters at Royal Copenhagen would never be able to work out what was right and what was wrong in a glaze that's designed to vary in colour on different parts of a pot. So that was the end of that glaze experiment!

"There were endless small problems like this all the time I was working with Royal Copenhagen. Take my jugs, for example." Ursula stood up and went to the far end of the table at which we were sitting to demonstrate. "Ideally, you should lightly wipe the rim of each jug after it's been glazed. Like this." She brushed the lip of a jug with a rectangular sponge. "That way, the glaze won't become too thick at the tip of the spout so the jug will pour better. But Royal Copenhagen refused to do this. I don't know why. It's a little thing perhaps, but it could have made the design just that little bit better and more practical."

\section{Design and Form}

Initially, Ursula Munch-Petersen designed the Ursula series in the same way that she designs a lot of her work, starting with two-dimensional sketches which she then converts into three-dimensional forms at home. After making a number of different shapes and sizes, she selected those that she thought were best and took them along to the factory to get samples made, glazed and fired.

"I prefer not to keep details exactly the same when I design things. So, while the handle here," She pointed to a middle-sized jug, "is straight, on the large jug I have indented it slightly. It's the same with these plates. Royal Copenhagen said they should be oval like the dishes, but I said no. So we kept them round.

"Sometimes there's no system in making a design, so you just cannot draw what you're thinking of. Like this bowl here." She showed me a faceted white bowl that was lying on its side just in front of me. "I did this in an afternoon, working with plaster of Paris, cutting off each side as I went along, until I ended 


\section{(C) $\mathrm{R}$ E}

up with this nine-sided bowl. There are a lot of things like this that you can do, but just can't talk about coherently."

Ole Jensen, the designer who worked in the room next door to her in the old Royal Copenhagen factory in Porcelainshaven, had this to say about her design process:

"Ursula used to make a lot of clay models. A lot of them went into the waste bin, but some went on to the next stage when they were made in plaster, and from these a few moved on to the model makers and were cast in moulds. It's really hard work because a lot of things need to be changed all the time. Remember, she wasn't working in a digital age then. There was no digital equipment at the factory, so everything was based on manpower in those days. It was really, really close to being... old fashioned. For sure, it's a good way to learn."

Finn Næss explained what happened then:

"Once we got the go-ahead to develop Ursula's ideas, I took her off to the Modelling Room and introduced her to the people there, in the same way that I did for other artists whose work we decided to develop. Ursula was very energetic and demanding - in the good sense of the word. She was very particular, for example, about the exact angle at which a handle should be fixed to the body of a cup, or how precisely a spout should be formed at its tip. This contrasted with the rather primitive look of the work that she'd made at home in her studio and then brought in to the factory..."

Ursula herself had more to say about teapots and spouts:

"I've made at least ten different teapot designs over the years. Some of them have had squarer handles; others lids over the top, rather than fitting inside; some spouts that are tapered, other that are cut off, and so on." She lifted the lid of one of the two teapots standing on the table between us. "It's difficult to get a really good fit when the lid is placed over the top of the teapot, and that's why I prefer this other style where the lid fits into the top. Ideally, too, a spout should be tapered like this teapot here, because that allows the tea to pour much better without dripping. This means I can make the spout itself a slightly different shape and angle to the body of the teapot. But, precisely because the tip of the spout is tapered like this, it is fragile and can get chipped easily. Hence this cut off style, which Royal Copenhagen wanted."

Another example of a problem with form concerned the spherical lids that were designed to act as both jug lids and small bowls in themselves.

"I designed these to be both lids and bowls in their own right. This is how I like to work - making multifunctional wares. There weren't any problems with these bowls as lids for as long as Royal Copenhagen made everything here in Denmark. But some years ago, they started to have some of the pots made abroad. This jug, for example, was made in Portugal, I think, before later being made by Nikko, a well-known porcelain factory in Japan. But the lid continued to be made in Denmark. But because there was more shrinkage in the Danish clay, the lids ended up being too small for the jugs, so they'd be too loose and 


\section{(C)R E A T I V E E N C O U N T E R S}

sometimes fall into the jug itself. It was such an elementary mistake to make. But they made it!"

Both Finn Næss and Peter Poulsen agreed with Ursula about this, although their perspective was somewhat different. Finn explained:

"There were a couple of things that happened that should never have happened with the Ursula series. One concerned production, the other stock.

"The first problem stemmed from the fact that Royal Copenhagen management began to get more conscious of production costs and started outsourcing. They decided to have the whole of the Ursula production done in Japan by Nikko. This meant we had to start production all over again, right from scratch. In other words, we found the original models, made copies of them, and sent the copies out to Japan, together with test moulds. Nikko then had to use these moulds with their clay, make adaptations, and send them back to us for inspection and approval. Ursula and I would examine them closely, make comments about how we wanted forms improved - pinching a lip here, softening a line there. I'd write everything down long hand in Danish and then give it to a secretary who'd translate it into English. Then we'd send the English instructions back to Nikko, who then made more tests, which they sent back to us for further examination. And so on. It was a lot of extra work, but, to their credit, Nikko did a really excellent job and their quality has always been really good.

"The second problem concerned stock. There was a time when a lot of stock was kept over in a warehouse in Malmö in Sweden... and orders were being taken here before being sent over there. This caused everyone a headache because the Ursula series consisted of so many different items. I mean, you had all the dishes, jugs, cups, and so on in the first place - a couple of dozen or more different forms. And then you had each of them glazed in all sorts of colours dark blue, light blue, russet brown and grey for the big bowls, for instance, and all seven colours for the little ones. That made for an awful lot of stock items, because each one had to be labelled differently - 1189571 for a small bowl with a dark blue glaze; 1189575 for a middle sized bowl; and 1189576 for a large bowl, both with the same glaze. Keep the same pot but change the glaze and you had a different stock label - 1188576 for yellow, for example, or 1187576 for dark green. You can see how easily pots could get mixed up. And they did. Either we got our customers' orders wrong, or we just couldn't deliver the right orders in time. As a result we lost a lot of customers - big ones, too. In this respect, you could say Ursula's concept was too complex..."

\section{Peter Poulsen continued:}

"You see, one tends to simplify things once production gets started. With the Ursula series, for example, we started with a transparent white glaze on the underside of each dish, within the foot rim, and glazed the rest of the dish in green, yellow, grey, or whatever coloured glaze. But once we started production, it became simpler to glaze the whole of each pot in the same colour, top and bottom. This is the sort of thing that goes on with every production line. It's normal procedure to change things as you go along during the first one or two years. But stock was something we should've thought about and worked out beforehand. Whether that was Marketing's 


\section{(C)R E A T I V E E N C O U N T E R S}

or Ursula's fault isn't clear in my mind. But one thing I do know. If she'd been told about the potential problem, she would have listened to advice..."

What, then, was the role of the Marketing Department in development of the Ursula series? Did the marketing people talk to Ursula about consumer tastes or advise her to change her designs at all? At this she laughed sadly:

“Designers weren't allowed to participate in meetings with marketing people. I know it sounds crazy, but that's how it was. I don't know why. Maybe it had something to do with the fact that we designers are immersed in design history and are influenced by one aesthetic movement or another, while the young girls in fashionable clothes and high heels who were in marketing knew absolutely nothing about Bauhaus and design schools like that. It struck me that marketing people were more concerned with copyright than with design.

"So I wasn't ever involved in a discussion of forms with marketing people. At the very beginning, they insisted on my making round serving dishes because they said that the oval ones wouldn't sell. In fact, they were quite wrong. It was the oval dishes that sold, not the round ones, which were then discontinued! They also wanted me to develop the series beyond just serving dishes. That's why cups were added, for example."

\section{Ole Jensen concurred:}

"The Marketing Department in Royal Copenhagen was much more focussed on luxury products than on selling everyday common pieces. It was more trained to tell stories about luxury life in contrast to daily life. This is one of the reasons, I think, that the Ursula series hasn't worked commercially."

It was, therefore, the product development rather than marketing department that gave advice on designs, forms and glazes, as Ursula explained:

"Finn Næss acted as intermediary and was really helpful during my time at Royal Copenhagen. He was involved in all kinds of meetings and told me what to do, saying things like: 'Now you should write a letter to the Director of the company,' or 'You'll just have to accept this glaze, or the whole things ends right here.' It was Finn who told me that my idea of having a kitchen series of ten bowls nestling inside one another had to be modified to five, so I agreed, even though I really wanted ten.

"The factory's mould-makers had a favourite word they used all the time when talking about making forms. What was it now? Ah yes! Compensate. You had to compensate for this or that when making forms. It's sad, isn't it? Words like this are part of a lost language, now that production's been shifted abroad and pots are no longer made in Denmark. Anyway, they would talk about how to compensate for what happened to the clay during drying and firing and so on. You know, the clay would sag a bit, so they had to compensate by making the forms more vertical. Things like that. And I had to go along with these adaptations, although I think that perhaps in some cases I shouldn't have." 


\section{(C) $R$ E}

\section{Corporate Practice}

One of the sticking points through the entire development of the Ursula series was the fact that Royal Copenhagen's management did not seem to want it to go into production. Ursula enjoyed telling the story of what happened:

"At the end of three years, the company said it wasn't interested in my designs. I wasn't prepared, though, to take no for an answer. I countered that I had to show something for the Arts Council bursary I'd held while at the factory designing the Ursula series, and told them I wanted to hold an exhibition of my work. Very reluctantly, the company agreed to let me show 50 pieces of each design for a month in its city centre store. That was at the end of May 1991.

"The show turned out to be a great success and everything sold out very quickly. Then the fun started. A well-known journalist, Henrik Steen Møller, wrote a fantastic review of my exhibition in the newspaper Politiken. A few weeks later, he wrote a scathing critique of a Royal Copenhagen product in the same newspaper. This led to an exchange between the CEO of Royal Copenhagen and the Editor-in-Chief of Politiken when the two men were sitting together on some board or other. The former complained about the newspaper publishing a critical article like that about a Royal Copenhagen product, so the latter asked to visit the factory to see things for himself. And, since he liked Steen Møller, the Editor-in-Chief took him along when he went. As they were going around, looking at all the work there, Henrik kept asking: 'Why don't you produce Ursula MunchPetersen's work? Is it too difficult? Are there technical problems? Or what?'

"And the Royal Copenhagen people couldn't answer these questions, so the CEO eventually said: 'Of course, it will come'. And once he'd said that, Royal Copenhagen had to do something about the design - especially after Steen Møller wrote about it in Politiken. They couldn't back out of things after that. Still, it took them some time to find the models and glaze tests we'd made while I'd been there, because they'd all been put away somewhere hard to find. As a result, things didn't get going for another two years or so."

Finn Næss had this to add:

"In a way, Ursula has always been her own marketing machine. She's been good at networking with people who matter - Erik Magnusson, for example, who was artistic consultant at Bing \& Grøndahl; Camilla Plum, the well-known cook; and, of course, Ebbe Simonsen, boss of Bing \& Grøndahl, who was Jewish and had his own connections with fellow Jews like the Editor-in-Chief of the Politiken newspaper and - I think I'm right in saying, though I may be wrong - Henrik Steen Møller, the journalist."

But connections or not, things didn't proceed smoothly.

“Ursula could see that the Board of Directors wasn't really interested in her work, but it didn't take account of her personality - of the fact that she was really engaged and believed in what she was doing. She'd move around the factory at will, pursuing her objectives with the Modelling Room, Glazing 


\section{(C)R E A T I V E E N C O U N T E R S}

Room and so on, and everyone liked working with her. And as a result, everyone wanted to see the Ursula dinnerware project succeed.

“What was missing in all this was that management didn't have any confidence in Ursula Munch-Petersen's decisions, even though all the factory floor workers did. As a result, everyone working with Ursula owed their loyalty to her, rather than to the company that employed them. We all wanted her to succeed."

Ursula herself clearly appreciated this, in spite of her reservations about the factory's management style.

"There were a lot of really good people working on the factory floor and I really learned a lot from them. They were all very different from one another, too, because in those days each 'room' (stue) had a very different cultural environment from the others. So the Modelling Room (modelstue) was totally different from the Decorating Room (malerstue), which was again different from the Glazing Room (glasurstue).

"But the factory as a whole had a special culture of its own. You always learned to look behind you and hold the door open for people carrying heavy loads of pots, for example. At the same time, some of the workers had almost been born in the factory so, as you can imagine, there were always plenty of intrigues going on. But I made really close friends with some of them..."

What emerged during the course of discussions was that Royal Copenhagen's management had trouble envisioning how the Ursula series should be positioned vis-à-vis the company's other products. Ole Jensen expressed this most clearly:

"Royal Copenhagen met with enormous success with its Mega floral design in the 1990s. This changed the company's international ambition and shifted its focus from artistic wares to its traditional designs. The Mega design was extremely important because it enabled the factory to survive and thrive. Perhaps it could have survived on the Ursula series and on my own designs, I don't know, but neither of these was typical of Royal Copenhagen ware - unlike the Mega design, which had a close link to the factory's classical tradition...

"If a company like Royal Copenhagen is to compete internationally, either it needs to be big and rich, or it has to focus on new pieces. Royal Copenhagen chose to focus on its tradition, and this is one of the reasons the Ursula series hasn't been a big commercial success. The Marketing people didn't feel comfortable with this kind of work..."

This observation led to Ole elaborating on Ursula Munch-Petersen's overall approach to pottery design vis-à-vis Royal Copenhagen's:

"When you buy Royal Copenhagen, you're buying luxury. Within this concept, the Ursula series is a kind of simple luxury, but in fact it represents much more a kind of... unluxury. It's a sort of schism, a paradox. When Ursula makes an unluxury product in the context of a luxury brand, then something's wrong..." 


\section{(C) R E A T I V E E N C O U N T E R S}

He expanded on this observation in the following manner:

"If you spend a lot of time in a porcelain factory, you begin to get interested beyond unique pieces in doing daily kitchen ware or dinnerware for common use... You get interested, too, not in mass production as such, but in production and in the reproduction of artistic qualities. So, from that point of view, Bing \& Grøndahl offered a really good chance to a young ceramicist like Ursula.

"At the same time, you find all sorts of different skills and different specialists in a factory, so you need to harmonize with them in order to be able to do your work... I think the Ursula series represents the very best of a craftsman's qualities, the best of Ursula Munch-Petersen herself, and the best of the art industry itself I mean, of the engineers, painters, formers, and so on... For this reason, I think it's a pity they've stopped making it this year.

"The quality of the Ursula design, the details, the sensitivity, the glazes and shapes are first class. Still, sometimes when you're working with factories and so on, even if you've done a good piece, you're never sure if it'll be a commercial success or not. This is because a lot of parameters have to be met beforehand. Artists often have no control over this part of... the game.

"So perhaps Ursula collaborated with the wrong company. Perhaps she could have had more success elsewhere. I don't know. How can I put it? As an artist, she had some eggs to lay, but perhaps she laid her eggs in the wrong nest. Sometimes, as an artist, you just can't control things. I think this is what happened with Ursula..."

Nevertheless, and in spite of discontinuing the Ursula series in 2011, Royal Copenhagen has occasionally taken advantage of its acclaim to boost its image:

"We worship Ursula Munch-Petersen," said Peter Poulsen proudly, "And we worship the Ursula series. A year ago, to commemorate 50 years of something or other, the company used Ursula as a logo or icon to tell the world what it made. Ursula has become its flagship design. But they never said it was Ursula Munch-Petersen who designed it. Instead, they just took the credit themselves. That was scandalous. I wrote and complained to management."

\section{Ole Jensen added:}

"From the very, very beginning I'm sure Royal Copenhagen thought Ursula was going to be one of the big ceramicists in Denmark, and for sure, one of its cleverest and most important. But, at the same time, the company thought she was in opposition to what they liked and what they wanted to make and do. And it's true. She has been a little bit in opposition to the brand ...

"In a way, Ursula is looking for opposition. In her line of thinking, to be an artist is not simply a matter of making the right form, or of being a craftsman. It's a way of searching for the opposition role - in a positive sense. As a designer, you have to be in opposition, and a company like Royal Copenhagen needs designers whose way of thinking is in contrast to everything that's accepted, both in the market and within the company itself. 


\begin{abstract}
"Sometimes, being in opposition means you can change something in the factory's mindset. But, in the case of Ursula, although she's produced important artistic work that is respected, what she did not manage to change was the mindset inside the company - the management's mindset, that is. I'm sure Ursula spent a lot of time discussing things. She's a rebel in the best sense of the word and you need to be a rebel when you collaborate with the business part of design. I don't mean that you need to enter into a big discussion all the time about the ideal way of doing things. You can be a rebel without being one in everything you do. In the beginning, Ursula was in opposition to how to do business, but - as I said - this creates a kind of schism: you're against being a part of the business because you're a part of it. I think Ursula could have learned a little bit about how to be more dynamic in the situation in which she found herself."
\end{abstract}

\title{
An Aesthetics of Production
}

Unlike many potters or other craftsmen, Ursula Munch-Petersen is known for being articulate about her work and about what makes a pot 'good' or 'bad'. Ole Jensen commented on her ability to see the potential in a design very early on in its process. She has a good 'eye' and uses her thoughts to formulate and explain why something is interesting, or not. He continued:

"She is also one of the few ceramicists with the intellectual power to write down her thoughts. She's written and talked a lot about handmade craftwork. You could call her, perhaps, a little too intellectual. But she's much better than a lot of artists, craftsmen, ceramicists, textile weavers and so on who aren't any good at talking. Their power is based only on the expression found in their work. Ursula likes to discuss her work in an intellectual way and she's always been very, very articulate...

"I've learned a lot from Ursula - both in terms of technical ways of doing things, of course, but mainly through her ideas about why one should make a new product. Ursula finds it difficult to make something new just because the market is looking for it. It's not that she's a romantic or anything like that; rather that it's important for her to find the right reason for making a new piece. For Ursula, it's extremely important to be critical - not in a negative, but in a positive way - to enable her to communicate human, rather than just commercial, values. Of course, working in a company can be very stressful, because it consists of many different parts, and you have to take part in the game. But the whole thing about Ursula was not to make a new collection as such, but to produce something that consisted of human and functional values..."

Such comments express an aesthetics of production, as seen by a designer. But Ole Jensen's ideas were shared by others working at the Royal Copenhagen factory. Peter Poulsen, for example, who is a chemical engineer by training, gave a succinct summary of his attitude to work:

"In our kind of work, we have to know what's 'good' and what's 'bad'. And that isn't something you can talk about or explain. It's not up for discussion at all. That's the way it is. Ursula knows what's good, and I like to think I 
do, too. To be able to make this distinction between 'good' and 'bad', you have, first of all, to know your materials. You have your transparent glazes and your matt glazes. You have to know which materials dissolve, and with what effects, and which don't. Things like that.

"And then you have to communicate. You have to enter into dialogue with other people, learn to speak the same language as they do, in order to be able to make the necessary adjustments to the thing you're working on. Ursula was really good at this sort of dialogue.

"Thirdly, you have to work. It's as simple as that. For me, I have my basic glazes that I then have to develop to create this effect or that. And that is simply a matter of work. Nothing else.

"And the driving force behind materials, communication and work is the idea. Without an idea, you've got nothing at all.

"At the same time, though, you've got to understand other people's work. Otherwise you can't communicate. That's why the Royal Porcelain Factory used to give us a training in everything. I mean, I first trained as a painter. That means I can paint Flora Danica - not well enough for production line purposes, maybe, but well enough to understand decorators when they talk to me about a problem they face.

"I also learned how to make moulds and press clay, and how to fire, of course. I had to, in order to be able to communicate and understand different people's problems. In the old Royal Porcelain Factory, all of us were trained as generalists before we became specialists. That's all gone now, of course."

The fact that the Ursula series has now been discontinued was cause for reflection by those to whom I talked. Both Ole and Peter, in their different ways, felt that the Ursula series represented a craft tradition that was now lost. First, let us hear Ole:

"There are still a lot of buyers - you may prefer to call them consumers - who can tell the difference between high and low quality. But when you no longer have the opportunity to make something in absolutely the best quality, then the public's ability to distinguish between good and bad quality disappears, in a way. This isn't to say that Royal Copenhagen now produces bad quality products. It's just that it's not possible any more for designers to be close to other craftsmen, like the model makers, painters, and so on. The Ursula service really represents the kind of quality you get in your hands when a designer works closely with the craftsmen and people who produce it. In a way, this is what the art industry has lost during the past 25 years, but it was probably unavoidable...

“It's a pity Ursula isn't in production any longer. I wonder why it's not possible to make money out of making and selling her dinnerware, although I'm sure it will be a very important part of Danish design and ceramic history for a lot of years in the future, because of its sensitivity and uniqueness... But one of the reasons why production has had to be stopped is because it's too expensive. For a commercial success, you need a good balance between production costs and retail 


\section{(C)R E A T I V E E N C O U N T E R S}

pricing. The Ursula series has been a little bit too expensive in its production because of its high quality.

“This has always been the craftsman's dilemma, right through history. It was a dilemma for William Morris, a dilemma for the Bauhaus. What happens is that work based on an idealistic tradition of producing the best and highest quality pieces for everyday users ends up consisting of luxury items. Their prices are always a little too high."

Peter Poulsen talked about this sense of history and loss from his viewpoint within the company:

"If there's one thing stops me from walking out of this job, it's history. I mean, I've inherited other people's hard work. The transparent glaze that we still use was first made by the founder of the Royal Porcelain Factory more than two centuries ago. It's basically still the same recipe. Of course, over the years, we've added to it, and we're still doing so, but I don't want all that accumulated knowledge to disappear just because I retire and there's nobody left at the factory who knows what I know and who can continue my work.

"So that's what keeps me going. That and the fact that the people I work with here are fantastic. They're so committed, you know. Committed to the work they do and to what they produce. In spite of everything.

"And it seems to me that tit's all going to be lost. In the same way that we've almost lost the skill of how to decorate porcelain. In the old days, the Royal Porcelain Factory in Frederiksberg used to employ two thousand people. Now, we've got just fifty women working in the Decorating Room here in Glostrup, eighty of us overall...

"I learned the basics of chemical engineering from my teacher at Technical University, of course, but since then everything I've learned has been through experience. You learn through your fingertips in my job." Peter rubbed two of his fingers on his thumb. "This isn't knowledge that you can see or read about, even though some people believe all you have to do is make a video of something for other people to be able to do what's wanted. But learning with your fingertips isn't knowledge you can see or pass on just like that. A lot of people just don't understand that."

\section{Conclusion}

This case is about craftsmanship: about conceiving, making, modelling, glazing and firing clay, in such a way that the finished product - an oval platter, lidded jug, or cake plate - is appealing in itself, while contributing to a class of other products, in this case tableware manufactured by Royal Copenhagen.

Craftsmanship of all kinds is founded on highly developed skills: here, a potter's or modeller's bodily understanding of the plasticity of clay and the accompanying possibilities and limitations of form afforded by it; and a chemical engineer's hands-on experience with certain ingredients - quartz, 


\section{(C) $\mathrm{R}$ E}

feldspar, and a variety of pigments - that, mixed in the right proportions, produce attractive colours appropriate to the forms. Their relentless pursuit of excellence allowed Ursula Munch-Petersen, Peter Poulsen and their co-workers to take pride in their work, while anchoring them in tangible reality (Sennett 2008: 21). The case reveals the interaction between head and hand, as those concerned sought, through many trials and occasional errors, to 'grasp' at solutions to the problems they faced. As Peter Poulsen succinctly summarized a lifetime of working with glazes (coincidentally echoing the thoughts of Richard Sennett [2008: 238]): 'You learn through your fingertips in my job.' Touch is the arbiter of both form and colour when working with clay.

Clay, like food, is both good to eat (bonne à manger) and good to think (bonne à penser). In one formulation, 'earth must no longer be what men eat but must instead be cooked, like food, in order to enable men to cook what they eat' (Lévi-Strauss 1988: 176). A shapeless mass is first prepared, then given form, before being dried, decorated and cooked in a kiln. No wonder, then, that there are parallels in the myths explaining the origin of cooking fire and those that of clay (Lévi-Strauss 1988: 50).

The pots that emerge are used primarily for food and drink. That is the purpose of Ursula dinnerware: to be usable, practical, multipurpose, and sturdy. But, in addition to this functional discourse, people talk about Ursula MunchPetersen's (and other) pots in a different way. Cups, jugs and dishes form a family (Munch-Petersen 1991), which has 'grown up' over many years of hard work (Nielsen 2004: 145). Individual pieces 'mingle on the table in appetizing harmony' with their 'rich forms and generous sizes' (Royal Copenhagen pamphlet). Words like care, fresh, friendliness, gentleness, joy, mild, natural, and warmth are used to express the potter's, as well as users', relations to the Ursula range (Figueroa 2011). Here we find ourselves immersed in a discourse of functional beauty, which, in the tradition of $19^{\text {th }}$ and early $20^{\text {th }}$ century craft movements in both England and Japan (Moeran 1997), imbues inanimate objects with human characteristics, and sets the artificial apart from the natural. Thus is the metamorphosis of clay transformed into the anthropomorphosis of material culture (Sennett 2008: 120-141).

Clay is good to reflect upon in another way. The fact that she decided to use a medium that she hadn't experienced before, faience, forced Ursula Munch-Petersen to think of a different way to conceptualise her tableware. Yes, it should be functional. Teapot spouts had to pour properly; their handles should enable a balanced grip. But it should also be multi-functional where possible. Oval plates could serve as lids to similarly shaped bowls; differently sized bowls could nestle inside one another to save space when not in use. In the potter's words: 'the shapes of our utensils are like pictures of our actions'.

But faience is not porcelain, like the other products made at Royal Copenhagen; and it is not stoneware, of the kind that she has been accustomed to working with. Faience might make use of decorative motifs, but it is remarkable first and foremost for the clear colours with which the clay can be Page 19 of 23 Creative Encou7nters Working Paper \# 62 


\section{(C) $\mathrm{R}$ E}

glazed. Glazes, then, are good to think. Not only did Ursula envisage a tableware series glazed in more than a dozen colours; she realised the economic advantages of such an approach. It was clay forms that required the most labour; the more forms, the more labour was required to press or mould them; and the more labour required, the more expensive was production. By designing fewer forms, fired in multiple colours, Ursula Munch-Petersen provided the opportunity for a radical innovation in Royal Copenhagen's production line. She fulfilled the craftsman's role of being, as the designer Ole Jensen said, 'in opposition - in a positive sense'. Her thinking had that 'sharp social edge' required of thinking like a craftsman (Sennett 2008: 44).

That such a radical line of thought about clay did not materialize (or, in Ole Jensen's words, 'change the mindset inside the company') reflects another aspect of craftsmanship. There is a difference between how something should be done and then getting that something to work in the way that it should (Sennett 2008: 45). Both Peter Poulsen and Ursula Munch-Petersen concentrated on what they perceived as 'objective' standards: on the function, form, and colour of the pot itself. But their discipline and commitment were thwarted by the corporate structure in which they found themselves. Their desire to do a thing well for its own sake came up against other standards, other evaluations of their work (Sennett 2008: 9). They faced the truism that 'every new experience, every new impulse to communicate meets with obstacles in the process of expression, and at least a part of its originality, its immediacy, and its liveliness is sacrificed to these obstacles' (Hauser 1982: 21). It may be the idea that is the driving force behind an understanding of materials, the ability to communicate, and sheer hard work, as Peter Poulsen so succinctly said, but the evidence suggests that Royal Copenhagen's managers wanted to whittle the 'big idea' into something as little as politically possible, without throwing it out altogether.

That Ursula Munch-Petersen had an idea is not in doubt; nor was her ability to work hard and learn about materials. Was it, then, an inability to communicate that let her down? Not exactly. She was well connected with people outside the factory, and communicated well with enough people who 'mattered' to be her own 'marketing machine'. Moreover, time and time again, people commented on how well she interacted with those working in the modelling and glazing rooms at the factory, on how much people were prepared to do for her, and to work for her rather than the factory as such, because they wanted her to succeed. The only apparent failure to communicate on her part, therefore, lay with her dealings with the factory's management.

As Richard Sennett (2008: 54) has noted, the craftsman's workshop is 'a productive space in which people deal face-to-face with issues of authority'. It can glue people together through shared practices and procedures stemming from highly specialized skills, as Ursula herself remarks about Royal Copenhagen's 'factory culture'. But it also reveals who commands and who obeys. Informally, the potter's obvious skills and willingness to learn from others created a charisma that encouraged those on the shop floor to see her as 


\section{(C) $\mathrm{R}$ E}

some sort of 'leader'. Formally, however, as 'artist in residence', she was more or less outside the corporate structure of Royal Copenhagen, with no direct access to managerial staff and thus with no opportunity to communicate her ideas in person.

Being an 'outsider', and perhaps something of a 'rebel', may have blinkered Ursula Munch-Petersen from realizing fully that what was relayed as a difference in managerial outlooks (Royal Copenhagen versus Bing \& Grøndahl) was in fact a difference in genres, and that the problem she faced was not social, but in a sense material. Generally speaking, every newly created work owes more to previous work of that genre than to the inventiveness and originality of its creator (Hauser 1982: 31). While working for Royal Copenhagen, therefore, Ursula Munch-Petersen needed to subject her idea about multi-coloured faience tableware to the company's 'rules of grammar' (that is, the Royal Copenhagen brand) and its stylistic principles (hand-painted flowers in cobalt on a porcelain body), if she was to achieve fully her purpose (Hauser 1982: 433).

The fact that she opted for faience and disregarded hand-painted motifs in cobalt in some way, surely, singled the potter out as a 'maverick' in the eyes of Royal Copenhagen's management. Although trained in conventional ways, Ursula Munch-Petersen worked unconventionally. How then was she to solve the riddle of Kant's pigeon, whose flight is made possible by the very atmospheric pressure that seems to hinder it? By developing two lines of social relations to circumvent, as best she could, management resistance. First, she cooperated closely with factory floor workers; second, she activated external networks with the power to voice public criticism. She was not able to get rid of the constraints that went with her, in many ways advantageous, position in Royal Copenhagen (Becker 1982: 236) because, however rebellious, she could only achieve production of the Ursula tableware series by remaining a part of the company. So, she was also a professional who changed some decorative conventions, introduced varieties of multi-functional forms and had to accept, more or less, everything else thrown at her. In this respect, as Howard Becker (1982: 244) points out, it is sometimes hard to 'draw a firm line between the innovating integrated professional and the maverick'. But, in the end, her designs did take off and 'fly', though not with quite the success, perhaps, of your everyday pigeon.

Because the actual connection between inner impulse and objectification is unclear and in some ways puzzling, those to whom I talked resorted to stories as a way of talking about - at times, perhaps, idealizing and dramatizing - the genesis and development of the Ursula dinnerware series. These stories were not quite as bold as Beethoven's attribution of his Eroica symphony to the fate of Napoleon, or as surprising as Schubert's hearing the theme for his String Quartet in D Minor in the workings of a rusty coffee mill, but the linking, for instance, of an early version of Ursula to the decision by the well-known cook, Camilla Plum, to use it over a weekend when serving food in the Museum of 


\section{(C) R E A T I V E E E N C O U N T E R S}

Industrial Arts in Copenhagen served as important an anchoring device as the biblical tale of Adam and Eve in the Garden of Eden - not that either 'explanation', of course, explains the genesis of anything.

In a sense, 'everything is a story, a narrative, a sequence of events with characters communicating an emotional content. We only accept as true what can be narrated' (Zafón 2009: 139). People tell stories for two reasons: firstly, to transform private into public meanings (and sometimes vice-versa); and secondly, to provide a sense of agency in the face of disempowering events (Jackson 2002: 14-5). Both strategies involve evaluation.

Stories change our experiences of events. In talking to me about things that happened more than 20 years ago, my informants began to reflect and go over the ground of their lives, retracing their steps to rework reality and render it comprehensible, both to myself, an outsider, and to themselves as participants. Finn Næss, Ole Jensen, Peter Poulsen and Ursula Munch-Petersen all remarked at some point about how long ago the events that they were relating had taken place, about how much they had forgotten, but also about how much came back to them once they stopped to think about the people and the sequence of activities in which they were all involved. None of this would have happened without the intervention of the anthropologist (who, in other circumstances, might have been a journalist, a detective or consultant of some kind).

The term anthropology derives its origin from 'the words of human beings'. An anthropologist lives off the tales he is told by those he meets and, in turn, writes stories based on the stories he hears. In this respect, the anthropologist begins to draw near to the potter. He shapes his stories from a jumbled mass of data, just as a potter at the wheel shapes his vessels from a lump of wet clay. Each leaves his handprints on the material being worked (Benjamin 1968: 92). Thus does each try to 'grasp' and 'give shape' to reality. 


\section{(C) R E A T I V E}

\section{References}

Becker, Howard 1982 Art Worlds. Berkeley \& Los Angeles: University of California Press.

Benjamin, Walter 1968 Illusions. Edited and with an introduction by Hannah Arendt. New York: Schoken.

Figueroa, William 2011 ‘Ursula Munch-Petersen'.

http://www.williamfigueroa.com/ArtAndDesignCollections/UrsulaMunchPeter sen/ursula.html Accessed May 18, 2011.

Hauser, Arnold 1982 The Sociology of Art. London: Routledge \& Kegan Paul. Jackson, Michael 2002 The Politics of Storytelling: Violence, Transgression and Intersubjectivity. Copenhagen: Museum Tusculanum Press.

Lévi-Strauss, Claude 1988 The Jealous Potter. Translated by Bénédicte Chorier. Chicago: University of Chicago Press.

Moeran, Brian 1997 Folk Art Potters of Japan. London: Curzon.

Munch-Petersen, Ursula 1991 'En prøveproduktion i fajance 1991'. In Hverdagsstel Munch-Petersen Fajance fra Royal Copenhagen. København: Royal Copenhagen A/S.

Nielsen, Teresa 2004 Ursula Munch-Petersen. København: Rhodos.

Sennett, Richard 2008 The Craftsman. London: Allen Lane.

Zafón, Carlos Ruiz 2009 The Angel's Game. Translated by Lucia Graves. London: Weidenfeld \& Nicholson. 